\title{
STRATEGI KOMUNIKASI HUMAS PEMERINTAH KOTA SURABAYA DALAM MELAYANI DAN MENGGALI POTENSI MASYARAKAT MELALUI MEDIA SOSIAL
}

\author{
Adelia Masrifah Cahyani \\ Universitas Islam Negeri Sunan Ampel Surabaya \\ fatihatur@gmail.com
}

Article Info

\author{
Abstract
}

Article history:

Received 14 Februari 2020

Accepted 15 Maret 2020

Published 10 April 2020

Keyword:

Strategi Komunikasi,

Media Sosial, Humas

Pemerintah Surabaya
This article discusses how the communication strategy of the Surabaya City Government Public Relations in serving and exploring the potential of the community through social media. This study used a qualitative descriptive method.

From the results of this study, four findings were obtained. Firstly, in conveying messages through social media, the Surabaya City Government Public Relations, especially in conducting discussions with the social media team, to determine the market for the message. Secondly, social media content which is so varied according to what is happening in the community, especially in the city of Surabaya. Thirdly, the Public Relations of the Surabaya City Government holds a photo contest on social media every month. It is also a place to facilitate the aspirations and work of the citizens of the city of Surabaya. Fourth, in the use of social media, the Surabaya City Government Public Relations has its own segmentation which aims to make it easier for the public to sort out the information needed through social media.

Artikel ini membahas tentang bagaimana strategi komunikasi Humas Pemerintah Kota Surabaya dalam melayani dan menggali potensi masyarakat melalui media sosial. Penelitian ini menggunakan metode deskriptif kualitatif.

Dari hasil penelitian ini diperoleh empat temuan. Pertama, dalam menyampaikan pesan melalui sosial media Humas Pemkot Surabaya terlebih melakukan diskusi dengan tim media sosial sebelum menyampaikan pesan kepada khalayak. Kedua, konten media sosial yang begitu variatif sesuai dengan apa yang sedang marak di lingkungan masyarakat khususnya di Kota Surabaya. Ketiga, Humas Pemkot Surabaya mengadakan lomba foto di media sosial setiap bulannya. Hal itu juga sebagai tempat untuk memfasilitasi aspirasi dan karya dari warga kota Surabaya. Keempat, dalam penggunaan media sosial, Pemkot Surabaya memiliki segmentasi tersendiri yang bertujuan untuk memudahkan masyarakat dalam memilah informasi yang dibutuhkan melalui sosial media.

Copyright (C) 2020 Jurnal Ilmu Komunikasi

\section{Editorial Office:}

Program Studi Ilmu Komunikasi, Fakultas Dakwah dan Komunikasi, UIN Sunan Ampel Surabaya. Jl. Ahmad Yani 117 Surabaya, Jawa Timur, Indonesia.

Email: jurnalilkom@uinsby.ac.id 



\section{Pendahuluan}

Di era yang modern seperti saat ini, hubungan masyarakat (humas) atau public relations menjadi suatu hal yang penting di suatu perusahaan atau lembaga. Dimana posisi humas sangat dibutuhkan untuk mendukung kemajuan sebuah perusahaan. Oleh Seorang humas bisa dikatakan berhasil ketika mereka mampu membangun relasi dengan klien dengan baik. Dengan begitu peran seorang humas sangat berpengaruh terhadap perusahaan/lembaga.

Pada lembaga pemerintahan, humas memiliki tanggung jawab untuk dapat menjadi penghubung antar lembaga pemerintah, lembaga pemerintah dengan lembaga-lembaga non pemerintah, lembaga pemerintah dengan media dan antara lembaga pemerintah dengan aparaturnya serta masyarakat luas. Dalam perannya sebagai jembatan penghubung ini, Humas Pemerintah mengumpulkan, yang berkaitan dengan program atau kebijakan, aktivitas dan capaian yang diraih oleh lembaga hingga tanggapan lembaga atas respon, aspirasi dan opini yang berkembang di masyarakat terhadap lembaga tersebut, sehingga teknologi dalam berkomunikasi ini sangatlah penting.

Kemajuan teknologi terus berkembang dan mengalami perubahan seiring dengan perkembangan zaman, salah satunya mengolah dan menyebarkan informasi

adalah internet. Kehadiran internet membawa dampak tersendiri bagi dunia bisnis maupun institusi media, termasuk pula bagi dunia public relations. ${ }^{1}$ Selain itu pada dunia bisnis dan public relations atau hubungan masyarakat juga membawa dampak tersendiri sebagai saluran komunikasi baru dalam berhubungan dengan para publiknya. Praktisi humas memiliki saluran langsung dalam berkomunikasi dengan publiknya tanpa harus termediasi melalui awak jurnalis bahkan lebih dari itu internet juga mampu mengubah hubungan komunikasi antara keduanya.

Internet didefinisikan oleh Tom Kelleher sebagai jaringan global yang dapat diakses oleh seluruh publik. Jaringan ini merupakan suatu sistem yang menghubungkan berbagai komputer, kabel, dan perangkat kabel serta nirkabel yang terhubung satu sama lain untuk membantu orang dalam pertukaran informasi di seluruh dunia. Perkembangan internet terus terjadi hingga akhirnya melahirkan suatu teknologi baru yakni Web 2.0 yang memperkenalkan dunia pada Web Sosial dan merupakan sebuah medium yang digunakan seorang dalam berkomunikasi dengan komunitas online yang mereka kehendaki. Salah satu bentuk aplikasi dari teknologi Web 2.0 adalah social media. ${ }^{2}$

Di tengah beragamnya media komunikasi saat ini, Humas Pemerintah

${ }^{2}$ Kelleher Tom, Public Relations Online; Lasting concepts for changing media, (USA: Sage Nick Mosdell, and Elliot Pill, Public Relations, (London: Sage Publications Inc, 2009), 114. Publications, 2007), 5

\section{Editorial Office:}

Program Studi Ilmu Komunikasi, Fakultas Dakwah dan Komunikasi, UIN Sunan Ampel Surabaya. Jl. Ahmad Yani 117 Surabaya, Jawa Timur, Indonesia.

Email: jurnalilkom@uinsby.ac.id 
Surabaya dituntut untuk dapat memilih media yang sesuai untuk dapat menyampaikan informasi baik untuk publik internal maupun eksternal. Saat ini sedang marak penggunaan media sosial khususnya di daerah perkotaan. Media sosial sudah menjadi kebutuhan primer dalam kegiatan komunikasi dalam kehidupan sehari-hari, bahkan media sosial sudah menjadi ketergantungan dalam pengggunaannya. Maka tidak mengherankan jika pengguna media sosial di Indonesia memiliki jumlah sangat besar, hal ini terbukti berdasarkan hasil survei yang dilakukan oleh We Are Social yang bekerjasama dengan Hootsuite, menyebutkan bahwa ada 130 juta orang Indonesia yang terbilang aktif di media sosial (medsos). Laporan We Are Social mengungkapkan bahwa total populasi Indonesia mencapai 265,4 juta jiwa, sedangkan pengguna internetnya setengah dari populasi, yakni sebesar 132,7 juta. Bila dilihat dari jumlah pengguna internetnya, maka bisa dibilang hampir seluruh pengguna internet di Indonesia sudah mengakses media sosial. We Are Social mengatakan 132,7 juta pengguna internet, 130 juta diantaranya pengguna aktif di media sosial. ${ }^{3}$

Untuk meningkatkan kesadaran masyarakatnya akan informasi mengenai Kota Surabaya, Humas Kota Surabaya melakukan hal-hal yang sama dengan lembaga lain melalui media sosial antara lain Facebook, Instagram dan Youtube.

${ }^{3}$ Simon Kemp, "Digital in 2018: World's Internet Users Pass 4 The Billion Mark" Oktober 10, 2018, https://wearesocial.com/blog/2018/01/globaldigital-report-2018.
Ketiga media sosial ini dipilih karena menurut hasil survei We Are Sosial menyatakan bahwa tiga teratas media sosial yang paling diminati di Indonesia, antara lain adalah YouTube 43\%, Facebook $41 \%$, Instagram 38\% dari 130 juta jiwa pengguna media sosial di Indonesia. ${ }^{4}$ Fungsi dari ketiga media sosial ini terdapat beberapa perbedaan yakni Facebook dan Instagram digunakan untuk memposting foto atau video singkat dan artikel megenai kota Surabaya, sedangkan Youtube memposting video-video kegiatan di kota Surabaya. Akan tetapi memiliki persamaan, yakni berbagi informasi mengenai program atau kebijakan, aktivitas dan capaian yang diraih oleh Kota Surabaya.

Media sosial terbilang menjadi salah satu media penyebaran informasi yang cukup efektif bagi banyak kalangan. Sehingga tidak jarang, akibat cepatnya penetrasi informasi di media sosial sebuah isu yang belum jelas kebenarannya begerak liar di luar kendali pihak-pihak yang terkait. Dalam kondisi seperti ini, Humas Pemerintah Kota Surabaya dituntut untuk memiliki kemampuan untuk mengelola media sosial agar informasi-informasi yang berkaitan dengan lembaga penaung dapat tersampaikan dengan baik. Selain itu humas juga harus mampu mengelola berbagai sumber informasi dan saluran komunikasi secara efektif, agar inforamsi yang seharusnya diketahui oleh

\footnotetext{
${ }^{4}$ Simon Kemp, "Digital in 2018: World's Internet Users Pass 4 The Billion Mark" Oktober 10, 2018, https://wearesocial.com/blog/2018/01/globaldigital-report-2018.
} 
masyarakat dapat di sampaikan kepada publik dengan tepat.

Humas Kota Surabaya sangat memiliki peranan penting dalam penyebaran informasi dan pembentukan citra Pemerintahan Kota Surabaya. Dilihat dari kinerja yang dimiliki, Humas Pemerintahan Kota Surabaya sangat bekerja keras dalam memberikan berbagai informasi dan sarana berkomunikasi dengan publik di Kota Surabaya. Humas Pemerintahan Kota Surabaya dalam mengembangkan hubungan yang baik dalam masyarakat dengan cara memberikan informasi secara meluas dan merata kepada masyarakat.

Hal ini menjadi tugas bagi humas Pemerintah Kota Surabaya dalam menanamkan kepercayaan kepada publik tidak hanya untuk memperoleh citra positif. Tetapi citra positif yang sudah dibangun perlu dipertahankan, karena memiliki pengaruh dengan reputasi pemerintahan. Begitu kepercayaan publik luntur akibat reputasi negatif maka akan sulit bagi permerintahan untuk memulihkan kepercayaan tersebut.

Dengan begitu banyaknya media sosial yang saat ini dapat kita temui dengan mudah, seorang Humas harus jeli dalam mengidentifikasi media sosial apa yang paling efektif dipergunakan sebagai media relation antara lembaga penaung dengan publiknya. Penggunaan media sosial yang tepat dapat meningkatkan citra atau reputasi lembaga dan penyampaian informasi yang tepat kepada publiknya, namun kesalahan dalam penggunaan media sosial juga dapat berakibat fatal. Oleh karena itu pemanfaatan media sosial harus terus dibarengi oleh peningkatan kemampuan dalam hal pengelolaan konten dan strategi kehumasan.

Dengan demikian, strategi komunikasi sangat diperlukan dalam mengelola isi dari media sosial. Dengan berbagai media sosial yang kini menjadi jembatan bagi Humas Pemerintah Kota Surabaya untuk berkomunikasi dengan masyarakat Kota Surabaya. Berdasarkan penjelasan di atas peneliti ingin mengetahui secara mendalam bagaimana strategi komunikasi praktisi Humas Pemerintah Kota Surabaya dalam mengelola media sosial sebagai media komunikasi dengan masyarakat.

\section{Kajian Pustaka}

\section{Strategi Komunikasi}

Strategi merupakan suatu perencanaan (planning) dan manajemen (management) untuk mencapai suatu tujuan. Tetapi untuk mencapai tujuan tersebut, strategi tidak berfungsi sebagai pedoman atau peta yang hanya menunjukkan arah dan tujuan saja, melainkan strategi juga harus menunjukan bagaimana taktik operasionalnya. Menurut J L Thompson yang dikutip dari Oliver mendefinisikan strategi sebagai cara untuk mencapai sebuah hasil akhir, hasil akhir menyangkut tujuan dan sasaran organisasi dan strategi kompetitif untuk masingmasing aktivitas. Demikian pula strategi komunikasi merupakan paduan dari perencanaan dan komunikasi (communication planning) dan manajemen komunikasi (communication management) untuk mencapai suatu tujuan. Strategi 
komunikasi menentukan berhasil tidaknya kegiatan komunikasi secara efektif. ${ }^{5}$

Dalam merumuskan strategi kepada khalayak, perlu diperhatikan pula bahwa setiap memiliki kekuatan penangkal yang bersifat psikologi dan sosial bagi setiap pengaruh yang berasal dari luar diri dan kelompoknya. Di samping itu khalayak tidak hanya dirangsang oleh satu pesan saja melainkan banyak pesan dalam waktu yang bersamaan. Itu artinya terdapat juga kekuatan pengaruh dari pesan-pesan lain yang datang dari sumber (komunikator) lain dalam waktu yang sama, maupun sebelum dan sesudahnya. Dengan demikian pesan yang diharapkan menimbulkan efek atau perubahan pada khalayak bukanlah satu-satunya "kekuatan", melainkan hanya satu di antara semua kekuatan pengaruh yang bekerja dalam proses komunikasi, untuk mencapai efektivitas.

Dengan begitu, maka pesan sebagai satu-satunya yang dimiliki oleh komunikator harus mampu mengunguli semua kekuatan yang ada untuk menciptakan efektivitas. Kekuatan pesan ini, dapat didukung oleh metode penyajian, media dan kekuatan kepribadian komunikator itu sendiri. Jadi dalam merumuskan strategi komunikasi, selain diperlukan perumusan tujuan yang jelas, juga perlu memperhitungkan kondisi dan situasi khalayak. Itulah sebabnya maka langkah pertama yang diperlukan ialah mengenal khalayak dan sasaran. Kemudian berdasarkan pengenalan dan komunikator yang dipilih, sesuai dengan situasi dan kondisi yang ada. Hal-hal yang perlu diperhatikan dalam perumusan strategi komunikasi ialah:

\section{a. Menyusun Pesan}

Setelah mengenali khalayak dan situasi dilingkungannya, maka langkah dalam perumusan strategi ialah menyusun pesan, yaitu menetukan tema dan materi. Syarat utama dalam mempengaruhi khalayak dari pesan tersebut, ialah mampu membangkitkan perhatian, perhatian adalah pengamanan yang terpusat. Dengan demikian awal dari suatu efektivitas dalam komunikasi sudah terpenuhi, dimana bangkitnya perhatian dari khalayak terhadap pesan pesan yang disampaikan.

Dalam masalah ini, Wilbur Schramm mengajukan syarat syarat untuk berhasil suatu pesan yang dikutip oleh Anwar Arifin dalam bukunya Strategi Komunikasi sebagai berikut ${ }^{6}$ :

1) Pesan harus direncanakan dan disampaikan sedemikian rupa sehingga pesan itu dapat menarik perhatian sasaran yang dituju.

2) Pesan haruslah menggunakan tandatanda yang didasarkan pada pengalaman yang sama antara sumber dan sasaran, sehingga kedua pengertian itu bertemu.

3) Pesan harus membangkitkan kebutuhan pribadidari sasaran dan menyarankan cara-cara untuk mencapai kebutuhan itu.

${ }^{6}$ Anwar Arifin, Strategi Komunikasi, Sebuah Pengantar Ringkas. (Bandung: CV. Armico, 1994), 68. 
4) Pesan harus menyarankan sesuatu jalan untuk memperoleh kebutuhan yang layak bagi situasi kelompok di mana kesadaran pada saat digerakkan untuk memberikan jawaban yang dikehendaki.

Selain yang tersebut di atas ada beberapa hal yang dapat menarik perhatian khalayak, mengemukakan bahwa dalam penyampaian pesan juga perlu memperhatikan 2 hal yang disebut dengan Availability (mudahnya diperoleh) dan Contrast (kontras). Availability, berarti isi pesan itu mudah diperoleh sebab dalam persoalan yang sama orang selalu memilih yang paling mudah, yaitu yang tidak terlalu banyak meminta energi atau tenaga. Contrast, berarti pesan itu, dalam hal menggunakan tanda-tanda dan medium memiliki perbedaan yang tajam dengan keadaan sekitarnya.

\section{b. Menetapkan Taktik}

Dalam dunia komunikasi pada teknik penyampaian pesan atau mempengaruhi khalayak itu dapat dilihat dari dua aspek yaitu menurut cara pelaksanaan dan menurut bentuk isinya. Hal tersebut dapat diuraikan lebih lanjut, bahwa yang petama, sematamata melihat komunikasi itu dari segi pelaksanaannya dengan melepaskan perhatian dari isi pesannya. Sedang yang kedua, yaitu melihat komunikasi itu dari segi bentuk pernyataan atau bentuk pesan dan maksud yang dikandung.
Oleh karena itu yang pertama menurut cara pelaksanaanya, dapat diwujudkan dalam dua bentuk, yaitu redundancy/repetition dan Canalizing. Sedangkan Canalizing menurut bentuk isinya dikenal teknik-teknik : informatif, persuasif, edukatif, dan koersif, sebagaimana penjelasannya dibawah ini. ${ }^{7}$

1) Redundancy atau repetition, adalah cara mempengaruhi khalayak dengan jalan mengulang-ngulang pesan kepada khalayak. Dengan teknik ini banyak sekali manfaat yang dapat di tarik. Manfaat itu antara lain bahwa khalayak akan lebih memperhatikan pesan itu, karana justru berkontras dengan pesan yang tidak diulang-ulang, sehingga ia akan lebih banyak mengikat perhatian.

2) Canalizing adalah memahami dan meneliti pengaruh kelompok terhadap individu atau khalayak. Untuk berhasil atau tidaknya komunikasi ini, maka haruslah dimulai dari memenuhi nilai-nilai dan standard kelompok dan masyarakat yang secara berangsurangsur merubahnya ke arah yang ingin dikehendaki. Dengan demikian pengaruh sumber (komunikator) lain akan menipis dan akhirnya akan hilang sama sekali. Dalam keadaan demikian itulah pesan-pesan akan mudah diterima oleh komunikan.

a) Informatif adalah suatu bentuk isi pesan, yang bertujuan

${ }^{7}$ Arifin. Strategi Komunikasi, 73-74. 
mempengaruhi khalayak dengan jalan memberikan penerangan atau informasi. Penerangan berarti menyampaikan sesuatu apa adanya, apa sesungguhnya, di atas fakta-fakta dan data-data yang benar serta pendapatpendapat yang benar pula. Atau seperti yang ditulis oleh Jawoto yang dikutip oleh Arifin :

- Memberikan informasi tentang fakta semata-mata, juga fakta bersifat kontropersial, atau

- Memberikan informasi dan menuntun umum ke arah pendapat.

- Teknik informatif ini, lebih ditujukan pada penggunaan akal pikiran khalayak, dan dilakukan dalam bentuk pernyataan berupa : keterangan, penerangan, berita dan sebagainya.

b) Persuasif berarti mempengaruhi dengan jalan membujuk, dalam hal ini khalayak digugah baik pikiran maupun perasaannya. Perlu diketahui, bahwa situasi mudah terkena sugesti yang ditentukan oleh : kecakapan untuk mensugesti atau menyarankan sesuatu kepada komunikan (suggestivitas), dan mereka itu sendiri diliputi oleh keadaan mudah untuk menerima pengaruh (suggestibilitas). Jadi di pihak yang mensugesti khalayak harus menciptakan situasi bagaimana khalayak itu supaya mudah terkena sugesti.

c) Edukatif sebagai salah satu usaha mempengaruhi khalayak dari suatu pernyataan umum yang dilontarkan, dapat diwujudkan dalam bentuk pesan yang akan berisi: pendapatpendapat, fakta-fakta, dan pengalaman-pengalaman.

Mendidik berarti memberikan sesuatu ide kepada khalayak apa sesungguhnya, di atas faktafakta, pendapat dan pengalaman yang dapat dipertanggung jawabkan dari segi kebenaran, dengan disengaja, teratur dan berencana, dengan tujuan mengubah tingkah laku manusia ke arah yang diinginkan.

d) Koersif berarti mempengaruhi khalayak dengan jalan memaksa. Teknik koersif ini biasanya dimanifestasikan dalam bentuk peraturanperaturan, perintah-perintah dan intimidasi-intimidasi. Untuk pelaksanaanya yang lebih lancar biasanya dibelakangnya berdiri suatu kekuatan yang cukup tangguh.

\section{c. Penggunaan Media}

Penggunaan media sebagai alat penyalur pesan atau ide, dalam rangka merebut pengaruh khalayak adalah suatu hal yang merupakan keharusan, sebab media dapat menjangkau khalayak yang cukup besar. Media merupakan alat penyalur yang juga 
mempunyai fungsi sosial yang kompleks. Sebagaimana dalam menyusun pesan dari suatu komunikasi yang ingin dilancarkan, kita harus selektif dalam menentukan media, dalam arti menyesuaikan keadaan dan kondisi khalayak. Selain itu kita harus memperhatikan faktor-faktor komunikasi dan hubungannya dengan situasi sosial-psikologis. Hal ini karena masing-masing media mempunyai kemampuan dan kelemahankelemahan tersendiri sebagai alat.

\section{Humas Pemerintahan}

Menurut kamus Institut of public relations (IPR) terbitan bulan November 1978 yang dikutip dari Edy Sahputra dan Faulina disebutkan bahwa "Praktik humas atau public relations adalah keseluruhan upaya yang dilakukan secara terencana dan berkesinambungan dalam rangka menciptakan dan memelihara niat baik dan saling pengertian antara suatu organisasi dengan segenap khalayaknya"8.

Jadi dapat disimpulkan bahwa humas atau public relations merupakan suatu komponen penting yang harus dimiliki oleh setiap organisasi, lembaga atau perusahaan sebagai penjembatan dan mengatur segala bentuk komunikasi yang nantinya akan menimbulkan saling pengertian antara suatu lembaga dan khalayaknya.

Dalam lingkungan pemerintahan istilah humas tampak lebih popular dibandingkan dengan public relations.

${ }^{8}$ Syahputra Edy \& Faulina, Profesional Public Relations, (Medan: USU Press, 2011), 3.
Bahkan organisasi yang membawahi humas pemerintah Indonesia dinamakan Bakohumas. Perbedaan pokok antara fungsi dan tugas humas yang terdapat di instansi pemerintah dengan non pemerintah (lembaga komersial) adalah tidak adanya unsur komersial walaupun humas pemerintah juga melakukan hal yang sama dalam kegiatan publikasi, promosi dan periklanan. Humas pemerintah lebih menekankan pada public services atau demi meningkatkan pelayanan umum.

Melalui unit atau program kerja humas, pemerintah dapat menyampaikan informasinya atau menjelaskan mengenai kebijaksanaan dan tindakan-tindakan tertentu serta aktifitas dalam melaksanakan tugas atau kewajiban-kewajiban kepemerintahannya. Humas pemerintahan juga memiliki peran dan fungsi sendiri dalam menjalankan tugas-tugasnya.

\section{Strategi Komunikasi Humas}

Menurut John D. Millett dalam bukunya, Management In Public Service The Quest For Effective Performance, yang dikutip oleh Rosady Ruslan artinya humas atau PR dalam dinas instansi atau lembaga pemerintahan terdapat beberapa hal untuk melaksanakan tugas utamanya, yaitu sebagai berikut ${ }^{9}$ :

a. Mengamati dan mempelajari
tentang hasrat, keinginan-
keinginan dan aspirasi yang
terdapat dalam masyarakat

\footnotetext{
${ }^{9}$ Rosady Ruslan, S. M.. Manajemen Purblic Relations dan Media Komunikasi, (Jakarta: PT Raja Grafindo Persada, 2012) 342.
} 
(Learning about public desires and aspiration).

b. Kegiatan memberikan nasehat atau sumbang saran untuk menanggapi apa sebaiknya dilakukan oleh instansi atau lembaga pemerintahan seperti yang dikehendaki oleh pihak publiknya (advising the publics about what is should desire).

c. Kemampuan untuk mengusahakan terjadinya hubungan memuaskan yang diperoleh antara hubungan publik dengan para aparat pemerintahan (ensuring satisfactory contact between public and government official).

d. Memberikan penerangan dan informasi tentang apa yang telah diupayakan oleh suatu lembaga atau instansi pemerintahan yang bersangkutan (informing and about what an agency is doing).

\section{Media Sosial Bagi Humas Pemerintahan}

Di era teknologi seperti saat ini media sosial menjadi hal yang tidak bisa lepas dari kehidupan sosial masyarakat, khusnya di kota-kota besar. Bahkan saat ini semua instansi, lembaga ataupun perusahaan memiliki media sosial masing-masing untuk berkomunikasi dengan khalayaknya secara global dengan cepat.

Menurut Ron Jones yang dikutip oleh Malita menjelaskan bahwa media sosial merupakan kategori media

\footnotetext{
${ }^{10}$ Laura Malita, Social Media Time Mangement Tools and Tips, Procedia Computer
}

online dimana orang-orang berbicara, berpartisipasi, berbagi, berjejaring dan ditandai dengan aktivitas online. Sebagian besar media sosial mendorong pengguna untuk berdiskusi, memberikan umpan balik, voting, komentar dan berbagi informasi sesuai dengan minatnya masing-masing. Media sosial lebih dari sekedar percakapan dua arah, lebih dari broadcast satu arah seperti media tradisional, media sosial memiliki keunikan yaitu dengan adanya ide tetap terhubung dengan site, sumber dan orang-orang lainnya. ${ }^{10}$

Saat ini ada banyak media sosial yang dapat kita temui ketika kita membuka internet. Untuk ini kita perlu mengetahui jenis-jenis media sosial yang cocok atau sesuai dengan tujuan kita. Ron Jones mengklasifikasi media sosial sebagai berikut:

a. Social sharing (Flickr, Snapfish, YouTube, dan Jumpcut).

Disini kita dapat membuat, mengupload dan membagi video dan foto dengan yang lain.

b. Social networks (Facebook, LinkedIn, MySpace, Instagram dan Twitte)

Pada jejaring sosial kita dapat menemukan dan terhubung dengan orang lain. Ketika terhubung, kita dapat terus mengikuti up-date informasi dari yang bersangkutan, seperti 
informasi kontak, kesukaan, posting, $\mathrm{dll}^{11}$.

Media sosial sangat penting untuk humas Pemerintahan, karena media sosial telah terbukti menjadi media penyebaran informasi yang cukup efektif di kalangan masyarakat saat ini. Akibat cepatnya informasi di media sosial, kadang-kadang sebuah informasi yang belum jelas kebenarannya bergerak liar di luar kendali pihak-pihak yang terkait. Dalam kondisi seperti ini, Humas Pemerintah dituntut untuk memiliki kemampuan mengelola media sosial agar informasi-informasi yang berkaitan dengan lembaga Pemerintahan dapat tersampaikan dengan baik.

Selain itu, Humas juga harus mampu mengelola berbagai sumber informasi dan saluran komunikasi secara efektif, agar informasi yang seharusnya diketahui oleh masyarakat dapat sampai kepada publik dengan tepat. Seperti yang sudah dijelaskan di atas mengenai beberapa media sosial, humas di haruskan memilih mana media sosial yang sesuai dengan kebutuhan humas dalam berkomunikasi dengan masyarakat. Setelah memilih media sosial dan memiliki akun dalam media sosial tersebut, hal yang harus dilakukan selanjutnya oleh humas ialah membuat

${ }^{11}$ Malita, Social Media, 748.

${ }^{12}$ Menteri Pendayagunaan Aparatur Negara Dan Reformasi Birokrasi RI (PAN-RB), Oktober konten untuk mengisi profil lembaga pada media sosial tersebut.

Pedoman Pemggunaan Media Sosial Instansi Pemerintah yang dikeluarkan oleh Menteri Pendayagunaan Aparatur Negara dan Reformasi Birokrasi (PAN-RB) RI menyebutkan 9 asas media sosial yaitu $^{12}$ :

1) Faktual, yaitu informasi yang disampaikan melalui media sosial berlandaskan pada data dan fakta yang jelas.

2) Disampaikan melalui media sosial sehingga dapat diakses dengan mudah dan diketahui oleh siapa saja, kapan saja, di mana saja.

3) Mendorong keikutsertaan dan keterlibatan (khalayak dengan cara menerima komentar, tanggapan, dan masukan kepada instansi pemerintah.

4) Interaktif, yakni komunikasi instansi pemerintah yang dilakukan melalui media sosial bersifat dua arah.

5) Harmonis, yaitu menciptakan hubungan sinergis yang saling menghargai, mendukung, dan menguntungkan di antara berbagai pihak yang terkait.

6) Etis, yaitu dengan menerapkan perilaku sopan, sesuai dengan etika dan kode etik yang ditetapkan, serta tidak merugikan orang lain dan menimbulkan konflik.

12,2018 , https://www.menpan.go.id/site/download/file/2917 -sosialisasi-pedoman-menteri-pan-dan-rb-no-20tahun-2012 
7) Kesetaraan, yaitu terbina hubungan kerja yang baik dan setara antara instansi pemerintah dan pemangku kepentingan.

8) Profesional, yaitu pengelolaan media sosial yang mengutamakan keahlian berdasarkan ketrampilan, pengalaman, dan konsistensi.

9) Akuntabel, yaitu pemanfaatan media sosial yang dapat dipertanggungjawabkan.

Dengan begitu banyaknya media sosial yang saat ini dapat kita temui dengan mudah di dunia maya, humas harus jeli dalam mengidentifikasi media sosial apa yang paling efektif dipergunakan sebagai media relation antara lembaga penaung dengan publiknya. Penggunaan media sosial yang tepat dapat meningkatkan citra atau reputasi lembaga, namun kesalahan dalam penggunaan media sosial dapat berakibat fatal. Oleh karena itu penggunaan media sosial harus terus disertai dengan peningkatan kemampuan dalam hal pengelolaan konten dan strategi kehumasan.

\section{Metode Penelitian}

Jenis penelitian ini menggunakan metode penelitian kualitatif deksriptif, yakni suatu penelitian yang dimaksudkan untuk mengumpulkan informasi mengenai subjek penelitian dan perilaku subjek penelitian pada suatu periode tertentu. Penelitian kualitatif deksriptif berusaha

13 Mukhtar, Metode Praktis Penelitian Deskriptif Kualitatif, (Jakarta: GP Press Group, 2013), 10-11. mendeskripsikan seluruh gejala atau keadaan yang ada, yaitu keadaan gejala menurut apa adanya pada saat penelitian dilakukan. ${ }^{13}$ Peneliti menggunakan metode ini karena peneliti ingin menjelaskan secara mendalam mengenai strategi komunikasi Humas Pemkot Surabaya melalui media sosial.

\section{Hasil Dan Pembahasan}

Media Sosial saat ini sudah menjadi suatu hal yang tidak bisa lepas dari kehidupan sosial manusia. Khususnya di kota-kota besar, yang sebagian besar hidupnya tergantung dengan media sosial. Melalui media sosial Humas Pemkot Surabaya melakukan komunikasi kepada masyarakat Surabaya. Berbagai upaya dan strategi yang dilakukan oleh Humas Pemkot Kota Surabaya agar pesan yang ingin disampaikan melalui media sosial bisa diterima oleh masyarakat dan tepat sasaran. Berdasarkan penelitian yang dilakukan dilapangan, maka Strategi Komunikasi Humas Pemerintah Kota Surabaya dalam Mengembangkan Potensi Masyarakat Melalui Media Sosial adalah sebagai berikut:

Melayani dan Menggali Potensi Masyarakat melalui Media Sosial

a. Pengelolaan Pesan Melalui Media Sosial

Pemerintah Kota (Pemkot) Surabaya Sebelum berkomunikasi, pengelolaan pesan merupakan hal 
utama yang wajib di perhatikan. Berhasil tidaknya suatu komunikasi itu dilihat dari keberhasilan pesan yang disampaikan tersebut. Dari hasil penelitian yang peneliti dapat melalui pengamatan maupun wawancara dengan informan, dalam mengelola sebuah konten yang akan di upload di media sosial, Humas Pemkot Surabaya melalui beberapa tahap seperti, rapat dengan tim media sosial untuk membahas mengenai hal apa yang sedang dibutuhkan masyarakat dan juga apa yang dikerjakan oleh Pemerintah Kota.

Dalam penyampaian pesan melalui media sosial, Humas Pemkot Surabaya membertimbangkan banyak hal dan memahami karakter dari komunikan atau masyarakat terlebih dahulu. Informasi yang disampaikan melalui sosial media pun dipilah dan dipilih sesuai dengan karakter dari komunikan.

Untuk mengetahui apa yang sedang tren dan menjadi kebutuhan masyarakat, dalam menyusun pesan selain melakukan rapat dengan tim media sosial, Humas Pemkot Surabaya juga melihat terlebih dahulu bagaimana pasar dari pesan yang akan di sampaikan melalui media sosial. Untuk mendapatkan reaksi atau pendapat dari masyarakat mengenai informasi yang sedang tren dan yang dibutuhkan masyarakat, admin media sosial Humas Pemkot Surabaya melakukan jajak pendapat melalui instasory sebelum mengunggah di media sosial. Jika unggahan ini mendapatkan banyak respon dari masyarakat tandanya unggahan ini di butuhkan masyarakat dan dapat menarik perhatian masyarakat.

Sebagai akun resmi media sosial pemerintahan, Humas Pemkot Surabaya tidak dibatasi untuk memuat sisi lain dari kota Surabaya. Unggahan yang ada di akun media sosial Humas Pemkot Surabaya tidak selalu membahas hal-hal yang berkaitan dengan pemerintahan saja, melainkan juga mengenai apa yang sedang viral di kota Surabaya. Penggunaan bahasa yang digunakan untuk menyampaikan pesan juga santai, tidak kaku dan terkesan formal seperti akun pemerintahan pada umumnya. Penggunaan bahasa yang santai dan Suroboyo banget, juga menjadi salah satu daya tarik masyarakat untuk membaca pesan yang tidak terkesan membosankan.

\section{b. Menentukan Taktik}

Salah satu upaya Humas Pemkot surabaya untuk mengajak masyarakat ikut serta dalam mempertahankan visi misi kota Surabaya, Humas Pemkot Surabaya mengadakan lomba melalui media sosial setiap bulannya. Lomba yang di adakan di media sosial antara lain lomba drone, lomba menulis, lomba foto dan beberapa lomba lain sesuai dengan kegiatan yang ada di Surabaya. Perlombaan yang rutin diadakan setiap bulannya di media sosial adalah lomba foto Instagram. Tema yang di gunakan untuk perlombaan setiap bulannya juga 
berbeda, tema ditentukan sesuai dengan apa yang sedang menjadi trending di bulan tersebut.

Selain untuk mengajak warga untuk ikut berpartisipasi dalam kemajuan kota Surabaya, melalui lomba ini Humas Pemkot Surabaya juga memberikan tempat untuk menampung aspirasi dan bakat-bakat dari warga kota Surabaya itu sendiri. Dan sebagai apresiasinya Humas Pemkot Surabaya memberikan hadiah berupa buku ataupun uang bagi para pemenang lomba. Hasil karya dari lomba-lomba yang diadakan oleh Humas Pemkot Surabaya juga nantinya bisa digunakan untuk materi paparan Walikota.

Selain itu untuk mempertahankan dan menumbuhkan rasa kecintaan warga kota Surabaya, Humas Pemkot Surabaya juga mememberikan energienergi positif melalui sosial media. Dengan mengutip pesan-pesan dari Ibu Walikota yang begitu semangat dan bekerja keras di harapkan warga juga ikut merasakan hal yang sama yang di rasakan oleh Ibu Walikota dalam menjaga kota Surabaya. Seperti yang dilakukan beberapa waktu lalu oleh Humas Pemkot Surabaya melalui media sosial pada saat kejadian Bom di beberapa gereja di Surabaya. Humas Pemkot Surabaya memberikan dukungan kepada warga kota surabaya untuk tetap semangat dan bersatu melawan kejahatan yang ada dikota surabaya.

Dengan strategi-strategi seperti itulah Humas Pemkot Surabaya berharap dengan proses komunikasi yang dilakukan melalui media sosial terus mendapatkan dukungan, perhatian serta kepercayaan dari masyarakat sehingga dalam membangun Kota Surabaya untuk menjadi lebih baik warga surabaya berada di satu titik perspektif dan tujuan yang sama, yaitu untuk mendukung Surabaya terus mendunia dengan tidak berhenti Bangga akan kota Surabaya.

\section{c. Media Sosial Sebagai Publikasi}

Media sosial yang Pemkot Surabaya adalah Instagram, Facebook, Twitter dan Youtube. Keempat media itu pada dasarnya media sosial merupakan media komunikasi yang sudah menjadi hal yang ketergantungan bagi masyarakat diera yang sekarang ini. Selain itu penggunaan media sosial memudahkan sesorang atau lembaga untuk berkomunikasi secara menyeleruh tanpa terbatas oleh waktu dan tempat. Media sosial sendiri juga dapat mempengaruhi pola pikir dan perilaku manusia sebagai penggunanya.

Penggunaan media sosial bagi Humas Pemkot Surabaya adalah untuk membantu aktivitas jalannya pemerintahan dan agar bisa lebih dekat dengan masyarakat. Setiap media sosial memiliki segmentasi masing dalam penggunaannya. Instagram konten unggahannya adalah potretpotret indah kota Surabaya. Twitter lebih pada informasi tentang kegiatan Pemkot Surabaya, profil kegiatan 
Walikota dan informasi kegiatan Pemkot. Facebook digunakan untuk share semua unggahan tentang Surabaya dan Youtube untuk unggahan mengenai video-video tentang kota Surabaya. Hal ini dimaksudkan agar masyarakat bisa lebih memfilter ingin informasi berdasarkan apa yang dibutuhkan.

Keunggulan yang dimiliki oleh media sosial humas pemkot surabaya adalah bisa memuat segala hal yang berhubungan dengan kota Surabaya tanpa terbatas bidang atau temanya. Jika dibandingkan dengan akun dinasdinas lain yang hanya memuat sesuai dengan bidang pekerjaannya, tetapi media sosial humas pemot Surabaya tidak terbatas dalam menyampaikan berbagai informasi di media sosial, selama informasi yang disampaikan bermanfaat dan tidak melanggar norma rasa dan budaya, informasi tersebut akan di unggah di akun media sosial humas pemkot Surabaya.

Selain itu diakun media sosial Instagram Humas Pemkot Surabaya memiliki sub tema yang dibahas setiap harinya. \#monaction untuk hari senin yang memuat video mengenai kota Surabaya, kemudian hari selasa \#Tuelinary yang membahas tentang kuliner-kuliner khas dan yang unik yang ada kota Surabaya. di haru Rabu ada \#Wedontrends, tema ini membahas segala hal yang sedang trending dikota Surabaya mengenai tempat-tempat atau apapun yang menarik di kota Surabaya. Selanjurnya dihari kamis ada \#Thrusimeet yang membahas tentang sosok-sosok inspiratif dan yang ada di kota Surabaya. \#TGIFCulture dihari Jum'at yang membahas tentang mitos atau fakta yang ada di kehidupan sehari-hari masyarakat Indonesia. Kemudian di hari Sabtu ada \#SaturdayCommunity yang membahas tentang komunitas-komunitas yang berpengaruh dan inspiratif di kota Surabaya dan yang terakhir \#Sungram di hari Minggu yang mengunggah ulang foto-foto dari warga kota Surabaya yang Instagramable.

Selain dengan menggunakan hastag sebagai invosi dalam keunggulan unggahannya, humas juga memiliki keunggulan dibandingakn dengan dinas lain dalam memuat kegiatan walikota. Humas pemkot Surabaya lebih memiliki tingkat kedekatan dengan ibu Walikota Tri Rismaharini dibandingan dinas lain, dimana hal ini dapat dilihat dari unggahan Bu Wali ngeVlog yang ada di akun media sosial Instagram.

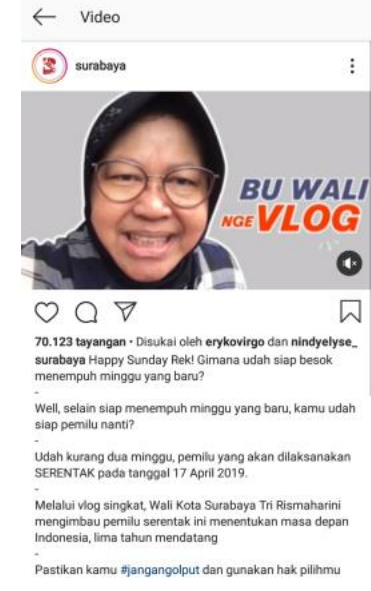




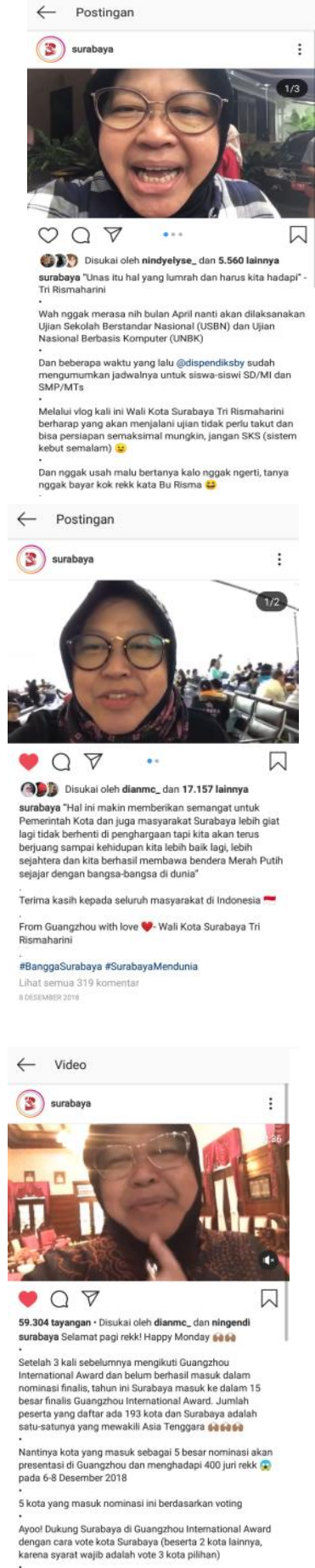

Gambar : Unggahan Bu Wali ngeVlog

Hal ini menjadi daya tarik tersendiri bagi followers media sosial humas pemkot Surabaya, dikarenakan hal ini menjadi salah satu yang sedang marak di kalangan anak muda dan kegiatan vlog ini lebih banayak dilakukan oleh kalangan anak muda dan dewasa. Sehingga humas pemkot Surabaya membuat konten Bu Wali ngeVlog sebagai bentuk inovasi baru dan diharapkan pesan yang disampaikan bisa lebih terarah karena pesan tersebut disampaikan oleh Ibu Walikota Surabaya.

Penggunaan tema pada setiap unggahan media sosial Humas Pemkot Surabaya ini bertujuan untuk mengahadirkan sisi lain dari kota Surabaya. jadi tidak hanya sekedar memuat mengenai kegiatan pemerintahan kota Surabaya saja. Dengan pengolaan pesan dan penggunaan bahasa yang baik diharapkan informasi yang ingin disampaikan oleh Humas Pemkot Surabaya kepada khalayak bisa berjalan efektif dan di terima oleh masyarakat.

СКкомпо $\equiv$

Pemenang Anugerah Media Humas 2017:

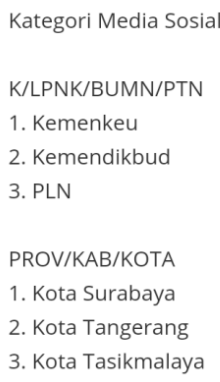

Gambar : Pemenang Anugerah Media Humas 2017

Keunggulan yang dimiliki oleh Media Sosial Humas Pemkot Surabaya yakni terletak pada akun media sosialnya sendiri. Selain mendapatkan centang biru di media sosial Instagram, Facebook dan 
Twitter. Akun media sosial Instagram milik Humas Pemkot Surabaya merupakan satu-satunya di Indonesia yang menggunakan nama kotanya langsung dan ada centang birunya. Humas Pemkot Surabaya mengemas sedemikian rupa akunnya agar mendapatkan perhatian lebih dari masyarakat dengan mengola pesan sebaik mungkin dan menyampaikan informasi berdasarkan fakta dan valid. Hal ini yang membuat media sosial Humas Pemkot Surabaya juara pertama dalam Anugerah Media Humas 2017 kategori media Sosial yang digelar Kementerian Kominfo RI.

\section{Kesimpulan}

Dari hasil penelitian di atas dapat disimpulkan bahwa strategi yang dilakukan oleh humas pemkot Surabaya dalam menyampaikan informasi kegiatan pemerintah kota Surabaya melalui media sosial menerapkan strategi komunikasi management by objective (MBO) dengan menentukan sasaran terlebih dahulu sebelum menyampaikan pesan, kemudian memantau perkembangan yang ada dimasyarakat, kemudian diskusi sebelum mempersiapkan konten setelah itu memberikan feedback kepada khalayak sasaran dengan memberikan apresiasi kepada khalayak dalam bentuk repost foto dan penghargaan.

Disamping itu inovasi-inovasi konten dan varian media sosial dalam kerangka keefektifan penyampaian pesan mengenai kegiatan pemerintah kota Surabaya kepada masyarakat merupakan langkah jitu untuk mewujudkan pelayanan kepada masyarakat. Sebagai upaya dalam mengajak masyarakat berpastisipasi dan mendapatkan perhatian dari masyarakat, humas mengadakan kegiatan lomba media sosial setiap bulan. Hal ini bisa mendekatkan masyarakat terhadap Pemerintah Kota Surabaya. Kegiatan lomba ini juga sebagai fasilitas untuk menampung aspirasi dan bakat-bakat dari warga kota Surabaya.

\section{Daftar Pustaka}

Arifin, Anwar. Strategi Komunikasi, Sebuah Pengantar Ringkas. Bandung: CV. Armico, 1994.

Edy, Syahputra \& Faulina. Profesional Public Relations. Medan: USU Press, 2011.

Franklin, Rob, Mike Hoga, Quentin Langley, Nick Mosdell, and Elliot Pill. Public Relations. London: Sage Publications Inc, 2009.

Kemp, Simon. "Digital in 2018: World's Internet Users Pass 4 The Billion Mark" Oktober 10, 2018, https://wearesocial.com/blog/2018/01 /global-digital-report-2018.

Malita, Laura. Social Media Time Mangement Tools and Tips, Procedia Computer Science. 3, (2011), 747757. https://doi.org/10.1016/j.procs.2010.1 2.123.

Menteri Pendayagunaan Aparatur Negara Dan Reformasi Birokrasi RI (PANRB). Oktober 12, 2018, https://www.menpan.go.id/site/downl oad/file/2917-sosialisasi-pedomanmenteri-pan-dan-rb-no-20-tahun-2012

Mukhtar. Metode Praktis Penelitian Deskriptif Kualitatif, Jakarta: GP Press Group, 2013. 
Oliver, Sandra. "Strategi Public Relations". Jakarta: Penerbit Erlangga, 2007.

Ruslan, Rosady, S. M. Manajemen Purblic Relations dan Media Komunikasi. Jakarta: PT Raja Grafindo Persada, 2012.

Tom, Kelleher. Public Relations Online; Lasting concepts for changing media. USA: Sage Publications, 2007. 